\title{
Biološka terapija u liječenju kroničnih upalnih bolesti crijeva
}

\section{Biological therapy in chronic inflammatory bowel disease treatment}

\author{
Dora Milakovići ${ }^{1}$ Marija Crnčević Urek ${ }^{*}$
}

\begin{abstract}
Sažetak. Upalne bolesti crijeva kronični su upalni poremećaji gastrointestinalnog sustava nepoznatog uzroka u koje ubrajamo Crohnovu bolest, ulcerozni kolitis i nedeterminirani kolitis. Ciljevi liječenja upalnih bolesti crijeva su postizanje i održavanje remisije bolesti, kao i mukozno cijeljenje. Biološka terapija predstavlja značajan napredak u liječenju s obzirom na to da može inhibirati upalnu kaskadu u podlozi kronične upalne bolesti te na taj način modificirati tijek i zaustaviti progresiju bolesti. S obzirom na to da je riječ o kompleksnim terapijama $s$ potencijalno ozbiljnim nuspojavama, njihova primjena zahtijeva iskustvo i provodi se prvenstveno u specijaliziranim centrima, ali sve više u općim i županijskim bolnicama.
\end{abstract}

Ključne riječi: biološka terapija; Crohnova bolest; ulcerozni kolitis

Abstract. Inflammatory bowel disease is a chronic infammatory disorder of gastrointestinal system with unknown cause, which include Crohn's disease, ulcerative colitis and undetermined colitis. The aim of treatment is to induce clinical remission of disease and to achieve mucousal healing. Biological therapy is a big progress in treatment because it can inhibite inflammatory cascade found in the base of chronic inflammatory disease, modify disease and stop its progression. That therapy is very complex with many possibly serious side effects, so its use requires experience and it is used mostly in specialised centers, but also more and more in other hospitals.

Key words: biological therapy; Crohn's disease; ulcerative colitis

\author{
${ }^{1}$ Medicinski fakultet Sveučilišta u Zagrebu \\ ${ }^{2}$ Zavod za gastroenterologiju, hepatologiju \\ i kliničku prehranu, Klinika za unutarnje \\ bolesti, KB Dubrava, Zagreb
}

*Dopisni autor:

Doc. dr. sc. Marija Crčević Urek Zavod za gastroenterologiju, hepatologiju i kliničku prehranu, KB Dubrava, Zagreb e-mail: urek.marija@gmail.com

http://hrcak.srce.hr/medicina 


\section{KRONIČNE UPALNE BOLESTI CRIJEVA}

Upalne bolesti crijeva kronični su upalni poremećaji gastrointestinalnog sustava nepoznatog uzroka u koje ubrajamo Crohnovu bolest, ulcerozni kolitis i nedeterminirani kolitis (oko $10 \%$ pacijenata). Etiopatogeneza nije u potpunosti razjašnjena, no smatra se da bolest nastaje interakcijom genetskih i okolišnih čimbenika koja vodi do prenaglašenog upalnog odgovora sluznice koji rezultira bolešću. Povećana propusnost crijevne sluznice, oštećenje membrane enterocita, pore-

Biološka terapija predstavlja revolucionarni zaokret u liječenju pacijenata s upalnim bolestima crijeva. Upotrebljava se preko 20 godina u kliničkoj praksi i danas predstavlja standardnu metodu liječenja ovih pacijenata.

mećaj imunoregulacije i adaptivni imunosni odgovor uzrokuju kod Crohnove bolesti diferencijaciju CD4+ T-limfocita u Th1 limfocite koji proizvode sljedeće citokine: IFN- $\beta$, IL-1, TNF- $\alpha$ i IL-6. Potonji privlače reaktivne metabolite kisika, čimbenik aktivacije trombocita (engl. platelet-acti- vating factor, PAF) i dušikov oksid, a oni pak dovode do nastanka tipičnih lezija. Kod ulceroznog kolitisa izraženiji je Th2 odgovor s aktiviranim IL-4, IL-5, IL-10 citokinima. Upravo su citokini koji se oslobađaju u upalnom procesu cilj djelovanja biološke terapije ${ }^{1,2}$.

\section{LIJEČENJE KRONIČNIH UPALNIH BOLESTI CRIJEVA}

Prva linija liječenja kroničnih upalnih bolesti crijeva je medikamentozna ili tzv. konzervativna terapija koja može biti konvencionalna i biološka, dok se kirurško liječenje primjenjuje u težim kliničkim slučajevima. U konvencionalnu terapiju, koja se može primijeniti u liječenju upalnih bolesti crijeva, ubrajamo aminosalicilate (sulfasalazin, olsalazin, balsalazid i različiti oblici mesalazina), glukokortikoide (prednizon, prednizolon, hidrokortizonske klizme i budesonid), analoge purina (azatioprin i 6-merkaptopurin) te metotreksat ${ }^{3}$, dok biološka terapija uključuje infliksimab, adalimumab, certolizumab, golimumab, natalizumab, vedolizumab, ustekinumab i tofacitinib ${ }^{4}$. Liječenje Crohnove bolesti i ulceroznog kolitisa ovisi o lokalizaciji i težini bolesti (slika 1 i 2$)^{5}$.

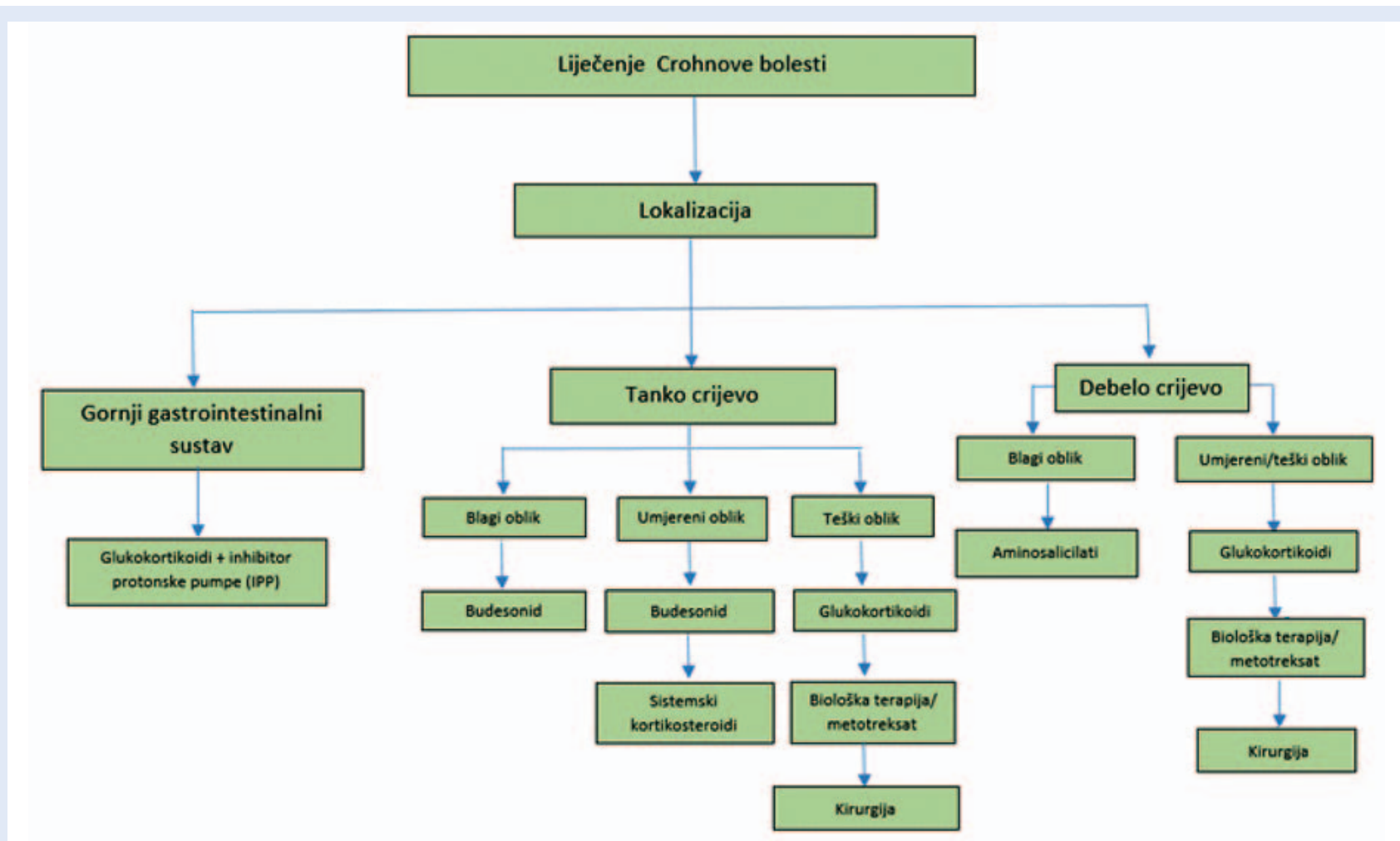

Slika 1. Postupnik liječenja Crohnove bolesti ${ }^{6}$ 


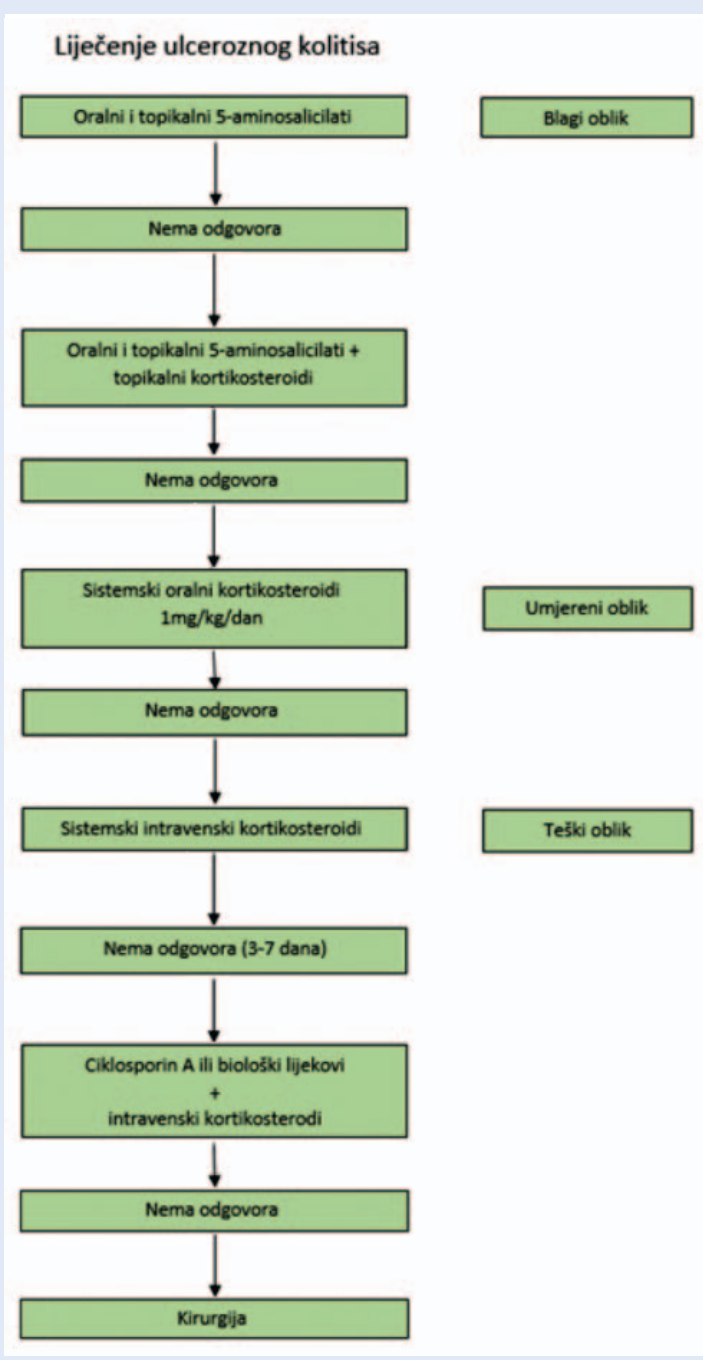

Slika 2. Postupnik liječenja ulceroznog kolitisa ${ }^{6}$

\section{BIOLOŠKI LIJEKOVI}

Biološki lijekovi definiraju se kao lijekovi s jednom ili više aktivnih supstancija koje su izvedene ili sintetizirane iz bioloških materijala, tj. živih organizama ili kultura stanica, najčešće gljivica, bakterija ili stanica sisavaca. Proizvode se metodom rekombinantne DNA tako da se geni potrebni za sintezu određenog proteina ugrađuju u genom matične stanice pomoću vektora, nakon čega se taj protein sintetizira i na kraju izolira iz stanice te se može upotrijebiti kao aktivna supstancija. Biološka terapija omogućuje ciljano djelovanje na upalne stanice i molekule koje imaju ulogu u patogenezi upalnih bolesti crijeva, zbog čega predstavljaju napredak u liječenju tih bolesti ${ }^{6}$.

\section{PODJELA BIOLOŠKIH LIJEKOVA}

Biološki lijekovi dijele se na anti-TNF- $\alpha$, antiintegrinske, anti-IL-12/23 lijekove i JAK-inhibitore (tablica 1$)^{4}$. Anti-TNF- $\alpha$ lijekovi najčešće su korišteni i u njih ubrajamo blokatore TNF- $\alpha$ receptora te solubilne receptore za TNF- $\alpha^{7}$. Blokatori TNF- $\alpha$ korišteni u upalnim bolestima crijeva su infliksimab, adalizumab, certolizumab te golimumab, s tim da se infliksimab i adalizumab koriste i kod Crohnove bolesti i kod ulceroznog kolitisa, certolizumab samo kod Crohnove bolesti, a golimumab samo kod ulceroznog kolitisa ${ }^{4}$. Drugu skupinu anti-TNF- $\alpha$ lijekova čine solubilni receptori za TNF, kao što su etanercept i onercept. Antiintegrinski lijekovi djeluju na principu inhibicije stanične adhezije, trenutno su vrlo istraživani lijekovi i u tu skupinu ubrajamo natalizumab i vedolizumab koji se koriste u liječenju Crohnove bolesti, dok se za liječenje ulceroznog kolitisa koristi samo vedolizumab ${ }^{4-7}$. Osim TNF- $\alpha$ receptora, biološka terapija uključuje i blokatore receptora drugih citokina, kao što su IL-12 i IL-23, čije receptore blokira ljudsko monoklonsko protutijelo ustekinumab koji je odobren za liječenje psorijaze, psorijatičnog artritisa i Crohnove bolesti ${ }^{8}$. JAK-inhibitor tofacitinib odobren je za liječenje ulceroznog kolitisa.

Tablica 1. Podjela bioloških lijekova

\begin{tabular}{|c|c|c|c|c|c|c|}
\hline \multicolumn{4}{|c|}{ Crohnova bolest } & \multicolumn{3}{|c|}{ Ulcerozni kolitis } \\
\hline \multicolumn{2}{|l|}{ Anti-TNF- $\alpha$} & \multirow{2}{*}{$\begin{array}{l}\text { Antiintegrinski lijek } \\
\text { Natalizumab* }\end{array}$} & \multirow{2}{*}{\begin{tabular}{|l|} 
Anti-IL-12/23 \\
Ustekinumab
\end{tabular}} & \multirow{2}{*}{$\begin{array}{l}\text { Anti-TNF- } \alpha \\
\text { Infliksimab }\end{array}$} & \multirow{2}{*}{$\begin{array}{l}\text { Antiintegrinski lijek } \\
\text { Vedolizumab }\end{array}$} & \multirow{2}{*}{$\begin{array}{l}\text { JAK-inhibitor } \\
\text { Tofacitinib }\end{array}$} \\
\hline Blokatori TNF- $\alpha$ & $\begin{array}{l}\text { Solubilni } \\
\text { receptori za TNF }\end{array}$ & & & & & \\
\hline Infliksimab & Etanercept* & Vedolizumab & & Adalimumab & & \\
\hline Adalimumab & Onercept* & & & Golimumab & & \\
\hline Certolizumab* & & & & & & \\
\hline
\end{tabular}




\section{Farmakologija anti-TNF lijekova}

TNF- $\alpha$ jedan je od ključnih proupalnih citokina $u$ upalnim bolestima crijeva. Proizvode ga imunološke stanice, $\mathrm{tj}$. stanice prirođenog (makrofagi, dendritičke stanice) i stečenog imunološkog sustava (TH1 stanice) te neimunološke stanice kao što su fibroblasti i glatke mišićne stanice. Dva su biološki aktivna oblika TNF- $\alpha$ : topljivi TNF i TNF vezan za membrane. Njihova biološka aktivnost ostvaruje se vezanjem za TNF receptore koji su posebno pri-

S obzirom na kompleksnost samih bolesti, složenost liječenja, potencijalne nuspojave liječenja, kao i učestale potrebe za upotrebom kombinirane imunosupresije, ovu terapiju treba primjenjivati u centrima s iskustvom u primjeni biološke terapije.

sutni na TH1 stanicama, prirođenim imunosnim stanicama i fibroblastima. Vezanjem TNF- $\alpha$ za TNF receptor, receptor se aktivira te dolazi do oslobađanja proinflamatornih citokina iz makrofaga, aktivacije i proliferacije limfocita $\mathrm{T}$, proizvodnje kolagena u fibroblastima, regulacije endotelnih adhezijskih molekula odgovornih za migraciju leukocita i poticanje jetrenih reaktanata akutne faze. Četiri su monoklonska protutijela odobrena u liječenju upalnih bolesti crijeva: infliksimab, adalimumab, certolizumab i golimumab (certolizumab nije registriran u Republici Hrvatskoj za liječenje upalnih bolesti crijeva). Infliksimab, adalimumab i golimumab protutijela su skupine $\operatorname{lgG}_{1}$, s time da je adalimumab potpuno humanizirano protutijelo, dok su infliksimab i golimumab kimerična protutijela (humanizirana kombinirana s mišjim). Certolizumab je rekombinantno protutijelo koje sadržava kimeričan Fab fragment konjugiran polietilenglikolom kojem nedostaje Fc fragment. Navedeni anti-TNF- $\alpha$ lijekovi vežu se visokim afinitetom za topljivi i membranski TNF- $\alpha$ te na taj način sprječavaju njegovo vezanje za receptor, a time i aktivaciju receptora i posljedice aktivacije. Vezanje za membranski TNF- $\alpha$ potiče i povratni signal koji smanjuje otpuštanje citokina ${ }^{3-9}$. Infliksimab se primjenjuje u intravenskoj infuziji u standardnoj dozi od $5 \mathrm{mg} / \mathrm{kg}$ tjelesne težine, ali u skoro vrijeme očekuje se njegov supkutani oblik. Za razliku od njega, ostali
anti-TNF- $\alpha$ lijekovi (adalimumab, certolizumab i golimumab) već se primjenjuju supkutano. Adalimumab se primjenjuje svaka 2 tjedna u standardnoj dozi od $40 \mathrm{mg}$ dok se certolizumab i golimumab primjenjuju svaka 4 tjedna, certolizumab u dozi od $400 \mathrm{mg}$, a golimumab u dozi od 100 $\mathrm{mg}^{3-4}$.

\section{Farmakologija antiintegrinskih lijekova}

Integrini jesu transmembranski proteini konstitucionalno izraženi na površini svih leukocita koji se vežu za proteine stanične membrane endotelnih stanica, čime se ostvaruje adhezija leukocita i endotelnih stanica. Ta komunikacija omogućuje cirkulirajućim leukocitima da se prihvate za vaskularni endotel, nakon čega se pomiču kroz krvne žile u tkiva. Proteini stanične membrane endotelnih stanica pripadaju skupini imunoglobulina, a među njima su najpoznatiji vaskularna endotelna adhezivna molekula (engl. vascular cell adhesion molecule, VCAM) i međustanična adhezivna molekula (engl. intercellular adhesion molecule, ICAM) koji su sastavni dio membrane endotelnih stanica, a IL-1 i TNF- $\alpha$ izrazito pojačavaju njihovu ekspresiju. Integrini se sastoje od heterodimera koji sadržavaju $\alpha$ i $\beta$ podjedinicu ${ }^{3-9}$. Natalizumab je humanizirano monoklonsko protutijelo skupine $\operatorname{lgG}_{4}$ usmjereno protiv $\alpha 4 \beta 1 \mathrm{i}$ $\alpha 4 \beta 7$ podjedinica integrina. Blokira interakciju između $\alpha 4 \beta 1$ i VCAM-1 u središnjem živčanom sustavu te između $\alpha 4 \beta 7$ i MAdCAM-1 u gastrointestinalnom sustavu. $\mathrm{S}$ obzirom na navedeno $u$ početku je korišten za liječenje multiple skleroze i Crohnove bolesti, no istraživanja su pokazala da je moguć razvoj progresivne multifokalne leukoencefalopatije zbog reaktivacije ljudskog polioma virusa (JC virus). Povučen je s tržišta 2005. godine, no od 2008. ponovo je odobren za liječenje pacijenata s umjerenim do težim oblikom Crohnove bolesti u kojih drugi način terapije nije postigao uspjeh. Primjenjuje se $u$ intravenskoj infuziji u dozi od $300 \mathrm{mg}$ svaka 4 tjedna, a prije uporabe preporučuje se testiranje na JC virus. Također, ne preporučuje se kombinirana primjena drugih imunosupresiva ${ }^{3-4}$.

Natalizumab nije registriran za liječenje upalnih bolesti crijeva u Republici Hrvatskoj. Vedolizumab je drugi antiintegrinski lijek, također humanizirano monoklonsko protutijelo iz skupine $\operatorname{lgG}_{4}$, ali za 
razliku od natalizumaba, usmjeren je samo protiv $\alpha 4 \beta 7$ podjedinice te djeluje selektivno u gastrointestinalnom sustavu blokirajući interakciju s MAdCAM-1, stoga nema opasnosti od razvoja progresivne multifokalne encefalopatije. Odobren je za liječenje Crohnove bolesti i ulceroznog kolitisa. Primjenjuje se $u$ intravenskoj infuziji $u$ dozi od $300 \mathrm{mg}$, inicijalno u indukcijskoj shemi u tjednu 0,2 i 6, te ako se postigne željeni odgovor na lijek u terapiji održavanja svakih 8 tjedana ${ }^{4}$.

\section{Farmakologija anti IL-12/23 lijekova}

Pretklinička istraživanja pokazala su prekomjernu ekspresiju interleukina 12 i 23, kao i prekomjernu sekreciju mononuklearnim stanicama lamine proprije te je dokazana njihova uloga u patogenezi Crohnove bolesti ${ }^{10}$. Navedeni interleukini, kao i njihovi receptori, građeni su od dviju podjedinica. Riječ je o podjedinicama p35 i p40 u slučaju interleukina 12 te podjedinicama p35 i p40 u slučaju interleukina 23. S obzirom na to da je jedna podjedinica navedenih interleukina zajednička, zajednička je i jedna podjedinica receptora, IL-12Rß1. Preostala podjedinica receptora interleukina 12 je IL-12Rß2, a interleukina 23 IL-23R. Trenutačno jedini lijek iz ove skupine koji se primjenjuje u liječenju Crohnove bolesti, psorijaze i psorijatičnog artritisa je ustekinumab ${ }^{8}$, humanizirano IgG protutijelo usmjereno protiv p40 proteina u IL-12 i IL-23, što sprječava vezanje na receptor IL-12Rß1 čime se smanjuje imunološki odgovor ${ }^{5}$. Prva doza je intravenska i ovisna je o tjelesnoj masi, a zatim se primjenjuje supkutano svakih 8 ili 12 tjedana u dozi od $90 \mathrm{mg}^{4}$.

\section{Farmakologija JAK-inhibitora}

Janus kinaze (JAK) citoplazmatske su kinaze koje sudjeluju u prijenosu signala od citokinskih receptora, kao što su receptori za INF-I, INF- $\gamma$, IL-2, $4,6,7,9$, 12, 15, 21, 23 i 27 koji sudjeluju u patogenezi upalnih bolesti crijeva, do transkripcijskih faktora (STAT). JAK obitelj uključuje JAK-1, JAK-2, JAK-3 i tirozin-protein kinazu- $2^{11}$. Tofacitinib je trenutačno jedini lijek iz skupine JAK-inhibitora odobren za liječenje upalnih bolesti crijeva, ali u tijeku je treća faza kliničke studije o uvođenju filgotiniba za liječenje Crohnove bolesti čiji se završetak očekuje do 2022. godine ${ }^{12}$. Tofacitinib inhibira sve JAK, ali prvenstveno JAK-1 i JAK-3 te se koristi u liječenju ulceroznog kolitisa. Njegova prednost je to što se može primjenjivati oralno, što pacijentima olakšava njegovu primjenu ${ }^{11}$. Preporučena doza za uvodno liječenje je $10 \mathrm{mg}$ peroralno dva puta dnevno tijekom 8 tjedana, dok se za terapiju održavanja preporučuje dvostruko manja doza ${ }^{13}$.

\section{BIOLOŠKA TERAPIJA U KLINIČKOJ PRAKSI}

Biološka terapija prva je terapija kojom se pokušava promijeniti prirodni tijek bolesti, stoga njeno uvođenje u kliničku praksu predstavlja značajan napredak u liječenju kroničnih upalnih bolesti crijeva. Primjena ovih lijekova zahtijeva dobro poznavanje tijeka bolesti i višegodišnje iskustvo liječnika u liječenju ovih bolesti s obzirom na kompleksnost fenotipova bolesti te moguće komplikacije i nuspojave lijekova. Danas se biološka terapija primjenjuje u svim većim kliničkim centrima u Republici Hrvatskoj, a sve je veći broj općih i županijskih bolnica koje se bave liječenjem ovim lijekom. Primjena ove terapije rezervirana je za uže specijaliste gastroenterologe ${ }^{14}$, koji su dosad koristili biološke lijekove isključivo u liječenju kroničnih upalnih bolesti crijeva, no istražuje se mogućnost njihove primjene u liječenju drugih imunoloških gastrointestinalnih bolesti, kao što su eozinofilni gastroenteritis, celijakija, eozinofilni ezofagitis, autoimune enteropatije i autoimuni hepatitis ${ }^{15}$. Ograničenje primjene bioloških lijekova može biti vrlo visoka cijena, no to se pokušava riješiti biosličnim lijekovima, čiji je aminokiselinski slijed gotovo jednak originalnom lijeku, ali postoji razlika u glikozilacijskom obrascu. Bioslični lijekovi jeftiniji su od originalnog te se na tržištu pojavljuju nakon isteka njegova patenta. U Europskoj uniji Europska agencija za lijekove (EMA) registrira biološke i bioslične lijekove na temelju vrlo visokih kriterija. Proizvođač je obavezan priložiti dokumentaciju kojom se dokazuje kvaliteta lijeka te rezultate kliničkih ispitivanja učinkovitosti i sigurnosti lijeka, a nakon stavljanja lijeka u promet, obavezan je pratiti sigurnost lijeka čije su nuspojave liječnici dužni prijaviti ${ }^{16}$.

\section{Biološka terapija Crohnove bolesti}

Za liječenje Crohnove bolesti danas se koriste infliksimab, adalimumab, certolizumab, natalizu- 
mab, vedolizumab i ustekinumab, s tim da je HZZO u Republici Hrvatskoj odobrio infliksimab, adalimumab, vedolizumab i ustekinumab kao lijekovi s terapijskom indikacijom za Crohnovu bolest. Infliksimab i adalimumab, koji su najdulje prisutni na tržištu, danas se već nazivaju „konvencionalnim biologicima”, a indicirani su za liječenje kompleksnih oblika Crohnove bolesti te liječenje odraslih i djece od 6 do 17 godina s teškom aktivnom bolesti refraktornom na terapiju kortikosteroidima i imunomodulatornu terapiju, kao i u slučaju nepodnošenja ili kontraindikacija za njihovu primjenu. Indikacija za primjenu vedolizumaba i ustekinumaba je umjereno do izrazito aktivna Crohnova bolest u odraslih pacijenata. Mogu se primjenjivati kao prva linija biološke terapije ili kao druga u pacijenata koji nisu postigli odgovarajući učinak, koji su izgubili odgovor na konvencionalnu terapiju ili na anti-TNF- $\alpha$ lijekove ili u slučaju dokumentiranog nepodnošenja takve terapije ${ }^{17}$. Ako je biološkim lijekom postignuta uspješna remisija, on se preporučuje u njenom održavanju te nema dokaza koji podržavaju prelazak na drugi biološki lijek ${ }^{18}$.

\section{Biološka terapija ulceroznog kolitisa}

Za liječenje ulceroznog kolitisa u Republici Hrvatskoj odobreni su infliksimab, adalimumab, golimumab, vedolizumab i tofacitinib. Infliksimab, adalimumab i golimumab indicirani su za liječenje umjereno teškog i teškog oblika ulceroznog kolitisa u pacijenata koji nisu adekvatno odgovorili na konvencionalno liječenje kortikosteroidima i 6-merkatopurinom ili azatioprinom te u slučaju nepodnošenja ili kontraindikacija za njihovu primjenu. Kod težih i fulminantnih slučajeva ulceroznog kolitisa infliksimab je prvi lijek izbora $u$ liječenju ovih pacijenata. Pokusne studije pokazale su da je incidencija kolektomije u razdoblju od tri mjeseca znatno niža u pacijenata koji su primali infliksimab u odnosu na one koji su primali placebo. Nadalje, zaključeno je da je indukcija u tri doze terapija izbora za prevenciju rane kolektomije ${ }^{19}$. Indikacija za primjenu vedolizumaba i tofacitiniba u liječenju ulceroznog kolitisa je liječenje odraslih pacijenata s umjerenim do teškim ulceroznim kolitisom koji nisu postigli odgovarajući odgovor ili su izgubili odgovor na konvencionalnu terapiju. Mogu se primjenjivati kao prva linija biološke terapije ili kao druga ako su pacijenti izgubili odgovor ili razvili nepodnošljivost na dosadašnje liječenje biološkom terapijom ${ }^{17}$.

\section{Održavanje remisije}

Prvi cilj liječenja upalnih bolesti crijeva je indukcija remisije, a zatim njezino održavanje. Izbor terapije održavanja remisije ovisi o tijeku i proširenosti bolesti te o učinkovitosti lijekova korištenih u indukciji remisije. Pacijenti ovisni o steroidima zahtijevaju liječenje azatioprinom ili metotreksatom s ili bez anti-TNF- $\alpha$ lijekova. Pacijentima koji dožive relaps na terapiji azatioprinom treba uvesti u terapiju biološki lijek. Ako je indukcija remisije postignuta biološkom terapijom, treba nastaviti s njom i u održavanju remisije. Terapiju održavanja anti-TNF- $\alpha$ lijekom treba primjenjivati najmanje godinu dana nakon ustanovljene duboke kliničke i endoskopske remisije bolesti. Ne postoje jasne smjernice o terminu prekida liječenja biološkom terapijom. Pacijente u remisiji treba redovito kontrolirati kliničkim, laboratorijskim i endoskopskim pretragama ${ }^{14}$.

\section{Kontraindikacije i nuspojave biološke terapije}

Kontraindikacije za primjenu biološke terapije uključuju preosjetljivost na djelatnu tvar, druge mišje proteine ili neku od pomoćnih tvari, klinički značajna, aktivna infekcija te zatajenje srca NYHA stupnja III i IV. Moguće nuspojave su brojne i mogu zahvatiti gotovo svaki organski sustav, od kojih neke mogu biti vrlo ozbiljne, kao što su razvoj ozbiljnih infekcija, reakcija povezanih s infuzijom, sistemskih i respiratornih preosjetljivosti, plućne embolije, intersticijske bolesti pluća, gastrointestinalnih perforacija te malignih i limfoproliferativnih bolesti među kojima valja istaknuti hepatosplenički T-stanični limfom koji do sada ima $100 \%$-tnu smrtnost ${ }^{13,20-24}$. Nadalje, primjena lijekova koji inhibiraju TNF- $\alpha$ dovodi se $u$ vezu s nastajanjem novih ili pogoršanjem postojećih kliničkih simptoma i/ili radiološkim nalazom demijelinizacijskih bolesti središnjeg živčanog sustava, uključujući multiplu sklerozu te demijelinizacijske poremećaje perifernog živčanog sustava, uključujući Guillain-Barréov sindrom. Nakon stavljanja infliksimaba u promet, primijećeni su slučajevi žutice i neinfektivnog hepatitisa koji je ponekad imao značajke auto- 
imunog hepatitisa. Postoje zabilježeni izolirani slučajevi zatajenja jetre koji su rezultirali transplantacijom jetre ili smrću ${ }^{20-22}$.

Tablica 2 prikazuje najčešće prijavljene nuspojave pojedinih skupina bioloških lijekova ${ }^{13,20-24}$.

\section{Biološka terapija u trudnoći}

Danas postoje podaci o liječenju trudnica s anti-TNF- $\alpha$ lijekovima. Drugi biološki lijekovi dostupni na tržištu u Republici Hrvatskoj nemaju dostupne podatke o primjeni u trudnoći. Podaci iz studija $\mathrm{s}$

Tablica 2. Najčešće prijavljene nuspojave pojedinih skupina bioloških lijekova

\begin{tabular}{|c|c|c|c|c|}
\hline Grupa nuspojava & Anti-TNF- $\alpha$ & Antiintegrinski lijek & Anti-IL-12/23 & JAK-inhibitor \\
\hline Infekcije & $\begin{array}{l}\text { Gripa, herpes zoster } \\
\text { infekcija, sepsa, celulitis, } \\
\text { apsces, infekcija gornjih } \\
\text { dišnih puteva, sinusitis, } \\
\text { bronhitis, pneumonija, } \\
\text { infekcija mokraćnih } \\
\text { puteva }\end{array}$ & $\begin{array}{l}\text { Nazofaringitis, } \\
\text { bronhitis, } \\
\text { gastroenteritis, infekcija } \\
\text { gornjeg dišnog sustava, } \\
\text { gripa, sinuitis }\end{array}$ & $\begin{array}{l}\text { Infekcija gornjeg dišnog } \\
\text { sustava, nazofaringitis, } \\
\text { sinuitis }\end{array}$ & $\begin{array}{l}\text { Pneumonija, gripa, } \\
\text { herpes zoster infekcija, } \\
\text { infekcija mokraćnih } \\
\text { puteva, sinuitis, } \\
\text { bronhitis, nazofaringitis }\end{array}$ \\
\hline $\begin{array}{l}\text { Poremećaj krvi i limfnog } \\
\text { sustava }\end{array}$ & $\begin{array}{l}\text { Neutropenija, } \\
\text { leukopenija, anemija, } \\
\text { limfadenopatija }\end{array}$ & - & - & Anemija \\
\hline $\begin{array}{l}\text { Poremećaji imunološkog } \\
\text { sustava }\end{array}$ & $\begin{array}{l}\text { Alergijske reakcije dišnog } \\
\text { sustava }\end{array}$ & $\begin{array}{l}\text { Anafilaktička reakcija, } \\
\text { anafilaktički šok }\end{array}$ & $\begin{array}{l}\text { Manje često: reakcije } \\
\text { preosjetljivosti (osip, } \\
\text { urtikarija) }\end{array}$ & - \\
\hline Psihijatrijski poremećaji & Depresija, nesanica & - & Manje često: depresija & Manje često: nesanica \\
\hline $\begin{array}{l}\text { Poremećaji živčanog } \\
\text { sustava }\end{array}$ & $\begin{array}{l}\text { Glavobolja, vrtoglavica, } \\
\text { omaglica, hipoestezija, } \\
\text { parestezija }\end{array}$ & Glavobolja, parestezije & Omaglica, glavobolja & Glavobolja \\
\hline Poremećaji oka & Konjunktivitis & Zamućen vid & - & - \\
\hline $\begin{array}{l}\text { Srčano-krvožilni } \\
\text { poremećaji }\end{array}$ & $\begin{array}{l}\text { Tahikardija, palpitacije, } \\
\text { hipotenzija, hipertenzija, } \\
\text { ekhimoza, navala } \\
\text { vrućine i crvenila }\end{array}$ & Hipertenzija & - & Hipertenzija \\
\hline Poremećaji dišnog sustava & Dispneja, epistaksa & $\begin{array}{l}\text { Bol u ždrijelu i grkljanu, } \\
\text { nazalna kongestija, } \\
\text { kašalj }\end{array}$ & Orofaringealna bol & Kašalj \\
\hline $\begin{array}{l}\text { Poremećaji probavnog } \\
\text { sustava }\end{array}$ & $\begin{array}{l}\text { Bol u abdomenu, } \\
\text { mučnina, } \\
\text { gastrointestinalno } \\
\text { krvarenje, proljev, } \\
\text { dispepsija, } \\
\text { gastroezofagealni } \\
\text { refluks, konstipacija, } \\
\text { poremećaj jetrene } \\
\text { funkcije }\end{array}$ & $\begin{array}{l}\text { Analni apsces, analna } \\
\text { fisura, mučnina, } \\
\text { dispepsija, konstipacija, } \\
\text { abdominalna distenzija, } \\
\text { flatulencija, hemoroidi }\end{array}$ & $\begin{array}{l}\text { Proljev, mučnina, } \\
\text { povraćanje }\end{array}$ & $\begin{array}{l}\text { Bol u abdomenu, } \\
\text { povraćanje, proljev, } \\
\text { mučnina, gastritis } \\
\text { dispepsija }\end{array}$ \\
\hline $\begin{array}{l}\text { Poremećaji kože i } \\
\text { potkožnog tkiva }\end{array}$ & $\begin{array}{l}\text { Psorijaza, urtikarija, osip, } \\
\text { svrbež, hiperhidroza, } \\
\text { suha koža, gljivični } \\
\text { dermatitis, ekcem, } \\
\text { alopecija }\end{array}$ & $\begin{array}{l}\text { Osip, pruritus, ekcem, } \\
\text { eritem, noćno znojenje, } \\
\text { akne }\end{array}$ & Pruritus & Osip \\
\hline $\begin{array}{l}\text { Poremećaji mišićno- } \\
\text { koštanog sustava }\end{array}$ & $\begin{array}{l}\text { Artralgija, mialgija, bol u } \\
\text { leđima }\end{array}$ & $\begin{array}{l}\text { Artralgija, mišićni } \\
\text { spazmi, bolovi u leđima, } \\
\text { mišićna slabost, umor, } \\
\text { bol u ekstremitetima }\end{array}$ & $\begin{array}{l}\text { Bol u leđima, mialgija, } \\
\text { artralgija }\end{array}$ & Artralgija \\
\hline $\begin{array}{l}\text { Opći poremećaji i reakcije } \\
\text { na mjestu primjene }\end{array}$ & $\begin{array}{l}\text { Reakcije vezane uz } \\
\text { infuziju, bol u prsištu, } \\
\text { umor, vrućica, reakcije } \\
\text { na mjestu injekcije, } \\
\text { zimica, edem }\end{array}$ & Pireksija & $\begin{array}{l}\text { Umor, eritem i bol na } \\
\text { mjestu injekcije }\end{array}$ & $\begin{array}{l}\text { Pireksija, periferni } \\
\text { edemi, umor }\end{array}$ \\
\hline
\end{tabular}


više stotina trudnica oboljelih od upalnih bolesti crijeva i artritisom pokazuju da anti-TNF- $\alpha$ terapija tijekom trudnoće nije povezana s nepovoljnim ishodima trudnoće kao niti s kongenitalnim anomalijama, ali uzimanje tih lijekova u kasnoj trudnoći povezano je s prisutnošću lijeka u krvi novorođenčeta i njihov dugoročni učinak na djecu još je nepoznat. Da bi se smanjila fetalna ekspozicija, preporučuje se ograničenje biološke terapije na prvih 30 tjedana trudnoće. Novorođenčad mora pomno pratiti neonatolog radi prilagodbe kalendara cijepljenja. Anti-TNF- $\alpha$ lijekovi izlučuju se u majčino mlijeko u malim količinama. Mali broj istraživanja pokazao je da nema nepovoljnih ishoda trudnoće u žena čiji su partneri bili na anti-TNF- $\alpha$ terapiji za vrijeme koncepcije ${ }^{25}$.

\section{Biološka terapija u liječenju upalnih bolesti crijeva u djece}

Kronične upalne bolesti crijeva u djece razlikuju se po nekoliko obilježja od istih bolesti u odraslih. U djece je bolest obično agresivnija, zahvaća veće površine crijeva, može se očitovati zastojem u rastu i razvoju te se s vremenom pogoršava, stoga postoje i terapijske razlike. Umjesto kortikosteroida, mesalazinskih preparata i imunomodulatora kao lijek izbora za indukciju remisije Crohnove bolesti vrlo često se koristi totalna enteralna prehrana, a elektivni pravovremeni kirurški zahvati također imaju važnu ulogu. Biološka terapija primjenjuje se i u djece. Prema ECCO smjernicama riječ je o infliksimabu i adalimumabu u slučaju Crohnove bolesti ${ }^{26}$, dok se u slučaju ulceroznog kolitisa, osim navedenih lijekova, koriste i golimumab i vedolizumab ${ }^{27}$, no Hrvatskoj su odobrena jedino dva lijeka, infiksimab i adalimumab. Indikacija za primjenu biološke terapije u Crohnovoj bolesti je umjereni i teški oblik aktivne bolesti, luminalni i/ili fistulirajući oblik te bolest rezistentna na standardnu terapiju enteralnom prehranom, kortikosteroidima i imunomodulacijskim lijekovima. Uporabu biološke terapije valja razmotriti u liječenju djece s kroničnim, perzistentno aktivnim ulceroznim kolitisom s prijetećim megakolonom, koja su refrakterna na terapiju aminosalicilatima i imunomodulacijskim lijekovima te rezistentna ili ovisna o kortikosteroidima. $U$ indukciji remisije infliksimab primjenjuje se u tri doze od $5 \mathrm{mg} / \mathrm{kg}$ tako da se druga doza daje dva tjedna nakon prve, a treća če- tiri tjedana nakon druge doze. U terapiji održavanja prethodnu dozu primjenjujemo svakih osam tjedana. Adalimumab se nakon indukcijske terapije primjenjuje u dvotjednim intervalima. Prva doza iznosi $160 \mathrm{mg}$ za djecu s tjelesnom masom većom od $40 \mathrm{~kg}$ te $80 \mathrm{mg}$ za djecu s tjelesnom masom nižom od $40 \mathrm{~kg}$, druga doza je dvostruko, a doza održavanja četverostruko niža od početne.

Za održavanje učinkovitosti liječenja, u značajnog broja pedijatrijskih pacijenata dozu anti-TNF- $\alpha$ lijeka nužno je povisiti ili interval između aplikacija skratiti. Kontraindikacije i nuspojave biološke terapije ne razlikuju se od kontraindikacija i nuspojava u odraslih ${ }^{28}$.

\section{Prekid uzimanja biološke terapije}

Danas ne postoje jasni stavovi i preporuke o terminu prestanka liječenja biološkom terapijom, neovisno o kojem se biološkom lijeku radi. Ove terapije su dugotrajne, s obzirom na to da je vjerojatnost relapsa po prestanku uzimanja bioloških lijekova izrazito visoka. Studije pokazuju da je rizik relapsa nakon ukidanja anti-TNF- $\alpha$ terapije $30-40 \%$ unutar jedne godine te veći od $50 \%$ unutar dvije godine. Čini se da pacijenti s prethodnom potrebom za povećanjem doze imaju veći rizik relapsa nakon prestanka uzimanja terapije. Nadalje, pacijenti s perianalnim fistulama imaju veći rizik od onih s luminalnim oblikom Crohnove bolesti i prekid anti-TNF- $\alpha$ terapije kod njih se ne preporučuje. Povlačenje anti-TNF- $\alpha$ lijekova koji su upotrijebljeni kao postoperativna profilaksa može biti povezano s većim rizikom recidiva. $S$ druge strane, prekid anti-TNF- $\alpha$ terapije u drugom trimestru trudnoće pokazalo se sigurnim za majku i za dijete. S obzirom na rizik od relapsa, pacijente koji su prestali uzimati biološku terapiju treba pomno nadzirati. Povišenje CRP-a obično se pojavi nekoliko mjeseci prije relapsa. Nastavak s istom biološkom terapijom obično je siguran i djelotvoran, a istodobna primjena imunomodulatora smanjuje rizik od neuspješnog djelovanja i infuzijske reakcije ${ }^{29}$.

\section{ZAKLJUČAK}

Biološka terapija predstavlja revolucionaran zaokret u liječenju pacijenata $s$ upalnim bolestima crijeva. U kliničkoj praksi primjenjuje se više od 
20 godina, stoga danas predstavlja standardnu metodu liječenja ovih pacijenata. S obzirom na kompleksnost samih bolesti, složenost liječenja, potencijalne nuspojave liječenja, kao i učestale potrebe za upotrebom kombinirane imunosupresije, ovu terapiju treba primjenjivati u centrima s iskustvom u primjeni biološke terapije, uz trajni nadzor pacijenta.

Izjava o sukobu interesa: Autori izjavljuju da ne postoji sukob interesa.

\section{LITERATURA}

1. Fauci AS, Braunwald E, Kasper DL, Hauser SL, Longo DL, Jameson JL et al. (eds) Harrison Principi interne medicine. U: Glickman RM (ed.) Upalne bolesti crijeva (Ulcerozni colitis i Crohnova bolest). Split: Placebo d. o. o., 1997;1226-33.

2. Mardešić D et al. Pedijatrija. U: Dujšin M (ed.) Bolesti probavnih organa. 8. izdanje. Zagreb: Školska knjiga, 2016; str. 844-849.

3. Katzung BG, Masters SB, Trevor AJ. Temeljna i klinička farmakologija. U: McQuaid KR, ur. Lijekovi za liječenje probavnog sustava. 11. izdanje. Zagreb: Medicinska naklada, 2011; str. 1087-1093.

4. Paramsothy S, Rosenstein AK, Mehandru S, Colombel JF. The current state of the art for biological therapies and new small molecules in inflammatory bowel disease. Mucosal Immunol 2018;11:1558-70.

5. Rodríguez Gandía M, Martínez González J. Enfermedad Inflamatoria Intestinal [Internet]. PROMIR Cursos para Médicos Internos Residentes [pristupljeno 24. 10. 2019.]. Dostupno na: https://promir.medicapanamericana.com/capitulo/570779c8f4d68bf008dbc64c \#58b0260cc3a9ae2d0069d82b.

6. Klanac M. Biološka terapija i drugi noviji pristupi liječenju kronične upalne bolesti crijeva u djece. Zagreb: Sveučilište u Zagrebu, Medicinski fakultet, 2018.

7. Marušić $M$, Mihaljević M. Farmakologija bioloških lijekova. Acta Med Croatica 2013; 67:125-30.

8. Simon EG, Ghosh S, Iacucci M, Moran GW. Ustekinumab for the treatment of Crohn's disease: can it find its niche? Therap Adv Gastroenterol 2016;9:26-36.

9. Damjanov I, Seiwerth S, Jukić S, Nola M. Patologija. U: Damjanov I, Aralina G, Batelja Vuletić L, Seiwerth S (ur.) Upala. 4. izdanje. Zagreb: Medicinska naklada, 2014; str. 58-60.

10. Strober W, Zhang F, Kitani A, Fuss I, Fichtner-Feigl S. Proinflammatory cytokines underlying the inflammation of Crohn's disease. Curr Opin Gastroenterol 2010;26:310-7.

11. Fernández-Clotet A, Castro-Poceiro J, Panés J. Tofacitinib for the treatment of ulcerative colitis, Expert Review of Clinical Immunology 2018;14:881-92.

12. IBD News Today. Filgotinib for Crohn's disease. Comish C, ur. [Internet] Philadelphia: BioNews Services; 2020 [pristupljeno 13. 2. 2020.]. Dostupno na: https://ibdnewstoday.com/filgotinib-crohns-disease/.

13. European Medicines Agency. Xeljanz: EPAR- Product Information. Colin de Verdière $M$ (ur.) [Internet] Amsterdam European Medicines Agency; 2019 [pristupljeno 24.
10. 2019.]. Dostupno na: https://www.ema.europa.eu/ en/documents/referral/xeljanz-article-20-procedureannex-i-ii-iii_hr.pdf.

14. Vucelić B, Čuković Čavka S, Banić M, Bilić A, Borzan V, Duvnjak $M$ et al. Hrvatski konsenzus o liječenju upalnih bolesti crijeva biološkom terapijom. Acta Med Croatica 2013;67:75-87.

15. Boban K. Biološka terapija. Zagreb: Sveučilište u Zagrebu, Medicinski fakultet, 2018.

16. Hrvatsko udruženje za Crohnovu bolest i ulcerozni colitis. Biološki i bioslični lijekovi. [Internet] Zagreb: Hrvatsko udruženje za Crohnovu bolest i ulcerozni colitis, 2019 [pristupljeno 24. 10. 2019.]. Dostupno na: https:// hucuk.hr/bioslicni-lijekovi-biosimilar/.

17. Hrvatski zavod za zdravstveno osiguranje. Indikacije smjernice. Matušin M (ur.) [Internet] Zagreb: Hrvatski zavod za zdravstveno osiguranje; 2019 [pristupljeno 24. 10. 2019.]. Dostupno na: https://www.hzzp.hr/indikacije-smjernice.

18. Torres J, Bonovas S, Doherty G, Kurcharzik T, Gisbert JP, Raine $T$ et al. ECCO Guidelines on Therapeutics in Crohn's Disease: Medical Treatment. Journal of Crohn's and Colitis, 2020;14:4-22.

19. Harbord M, Eliakim R, Bettenworth D, Karmiris K, Katsanos K, Kopylov U. Third European Evidence-based Consensus on Diagnosis and Management of Ulcerative Colitis. Part 2: Current Management. Journal of Crohn's and Colitis 2017;11:769-784.

20. European Medicines Agency. Remicade: EPAR - Product Information. Colin de Verdière M (ur.) [Internet] Amsterdam: European Medicines Agency; 2019 [pristupljeno 24. 10. 2019.]. Dostupno na: https://www.ema.europa. eu/en/documents/product-information/remicade-eparproduct-information_hr.pdf.

21. European Medicines Agency. Humira: EPAR - Product Information. Colin de Verdière $M$ (ur.) [Internet] Amsterdam: European Medicines Agency; 2019 [pristupljeno 24. 10. 2019.]. Dostupno na: https://www.ema.europa. eu/en/documents/product-information/humira-eparproduct-information_hr.pdf.

22. European Medicines Agency. Simponi: EPAR - Product Information. Colin de Verdière M (ur.) [Internet] Amsterdam: European Medicines Agency; 2019 [pristupljeno 24. 10. 2019.]. Dostupno na: https://www.ema.europa. eu/en/documents/product-information/simponi-eparproduct-information_hr.pdf.

23. European Medicines Agency. Entyvio: EPAR - Product Information. Colin de Verdière $M$ (ur.) [Internet] Amsterdam: European Medicines Agency; 2019 [pristupljeno 24. 10. 2019.]. Dostupno na: https://www.ema.europa. eu/en/documents/product-information/entyvio-eparproduct-information_hr.pdf.

24. European Medicines Agency. Stelara: EPAR - Product Information. Colin de Verdière $M$ (ur.) [Internet] Amsterdam European Medicines Agency; 2019 [pristupljeno 24. 10. 2019.]. Dostupno na: https://www.ema.europa.eu/ en/documents/product-information/stelara-epar-product-information_hr.pdf.

25. Calligaro A, Hoxha A, Ruffatti A, Punzi L. Are biological drugs safe in pregnancy? Reumatismo 2015;66:304-17.

26. Ruemmele FM, Veres G, Kolho KL, Griffiths A, Levine A, Escher JC et al. Consensus guidelines of ECCO/ESPGHAN on the medical management of pediatric Crohn's disease. Journal of Crohn's and Colitis 2014;8:1179-207. 
27. Turner D, Ruemmele FM, Orlanski-Meyer E, Griffiths AM, De Carpi JM, Bronsky J et al. Management of Paediatric Ulcerative Colitis, Part 1: Ambulatory Care-An Evidence-based Guideline From European Crohn's and Colitis Organization and European Society of Paediatric Gastroenterology, Hepatology and Nutrition. Journal of Pediatric Gastroenterology and Nutrition 2018;67:25729.
28. Kolaček S. Primjena biološke terapije u djece $s$ kroničnim upalnim bolestima crijeva. Acta Med Croatica 2013;67: 89-92.

29. Doherty G, Katsanos KH, Burisch J, Allez M, Papamichael K, Stallmach A et al. European Crohn's and Colitis Organisation Topical Review on Treatment Withdrawal ['Exit Strategies'] in Inflammatory Bowel Disease. Journal of Crohn's and Colitis 2018;12:17-31. 